\title{
STUDI FENOMENOLOGI PENGALAMAN ANGGOTA KELOMPOK DUKUNGAN SEBAYA MENDAMPINGI ORANG DENGAN HIV/AIDS MENJALANI HIDUP DI WILAYAH KABUPATEN KULON PROGO
}

\author{
Suratini ${ }^{1}$, Yuli Isnaeni ${ }^{2}$, \\ Fakultas Ilmu Kesehatan Universitas 'Aisyiyah Yogyakarta ${ }^{1,2}$ \\ Email : Suratini@unisayogya.ac.id
}

\begin{abstract}
The stigma and discrimination of people with HIV / AIDS in living their lives in the community makes their life spirit less so that they have an impact on their lives. Peer support groups of PLWHA are people who suffer from HIV / AIDS based on their life experience to care about PLWHA and always accompany their survival. Reaching groups or companions of PLWHA are needed for their existence. Forms of support provided can be in the form of ARV access, simple counseling of opportunistic diseases that attack PLWHA, in addition to the spirit of PLHIV survival by maintaining a balance of physical and spiritual health and living life in the community. Research objective: this is to get an idea of the meaning and meaning of members of peer support groups people living with HIV / AIDS live in the area of Kulon Progo Regency. Research method: a type of qualitative research with Indeep interviews with 8 members of the companion group. Analysis of the data used using the steps of Colaizzi. Data analysis in this study with Collaizi technique and produce 15 themes. The results of the study: The results of Indeepth Interview with 8 Participants who became supporters or mentions of PLWHA obtained 15 themes, namely background, length of time being a companion, number of mentors, support, constraints, mandaat support, attitude, companion feelings, activities, needs of PLHIV companions, principles / pillar of assistance, mentoring activities, work time, place of assistance and hope for health workers. Conclusion: a group of PLWHA has an important role in the life of PLWHA to receive their illness, undergo treatment, become friends to share, be empowered or independent again like before they are sick. Suggestion: companion group members continue to be passionate about being a mentor of PLHAs and motivating with the five main pillars of HIV / AIDS prevention.
\end{abstract}

Keywords: Peer support groups, People with HIV / AIDS

\section{PENDAHULUAN}

Situasi Masalah HIV-AIDS Tahun 1987 - September 2014, sejak pertama kali ditemukan tahun 1987 sampai dengan September 2014, HIV-AIDS tersebar di 381 (76\%) dari 498 kabupaten/kota di seluruh provinsi di Indonesia. Provinsi pertama kali ditemukan adanya kasus HIV-AIDS adalah Provinsi Bali, sedangkan yang terakhir melaporkan adalah Provinsi Sulawesi Barat pada tahun 2011( Ditjen PP \& PL Kemenkes, 2014) Secara kumulatif kasus HIV \& AIDS 1 Januari 1987 s.d. 30 September 2014, terdiri dari: HIV: 150296 orang dan AIDS: 55799 orang 
Data Ditjen PP dan PL Kemenkes (2014) sampai dengan tahun 2005 jumlah kasus HIV yang dilaporkan sebanyak 859, tahun 2006 (7.195), tahun 2007 (6.048), tahun 2008 (10.362), tahun 2009 (9.793), tahun 2010 (21.591), tahun 2011 (21.031), tahun 2012 (21.511), tahun 2013 (29.037) dan tahun 2014 (22.869). Jumlah kumulatif infeksi HIV yang dilaporkan sampai dengan September 2014 sebanyak 150.296. Jumlah infeksi HIV tertinggi yaitu di DKI Jakarta (32.782), diikuti Jawa Timur (19.249), Papua (16.051), Jawa Barat (13.507) dan Bali (9.637).

Faktor risiko penularan terbanyak melalui heteroseksual (61,5\%), penasun $(15,2 \%)$, diikuti penularan melalui perinatal $(2,7 \%)$, dan homoseksual $(2,4 \%)$. Angka kematian (CFR) menurun dari 3,79\% pada tahun 2012 menjadi 0,46\% pada bulan September tahun 2014 (Ditjen PP \& PL Kemenkes, 2014) Pada tahun 2013 terdapat sekitar 170.000 sampai 210.000 dari 220 juta penduduk Indonesia mengidap HIV/AIDS. Perkiraan prevalensi keseluruhan adalah $0,1 \%$ di seluruh negeri, dengan pengecualian Provinsi Paua, di mana angka epidemik diperkirakan mencapai $2,4 \%$, dan cara penularan utamanya adalah melalui hubungan seksual tanpa menggunakan pelindung. (Ditjen PP \& PL Kemenkes, 2014)

Jumlah kasus kematian akibat AIDS di Indonesia diperkirakan mencapai 5.500 jiwa. Epidemi tersebut terutama terkonsentrasi di kalangan pengguna obat terlarang melalui jarum suntik dan pasangan intimnya, orang yang berkecimpung dalam kegiatan prostitusi dan pelanggan mereka, dan pria yang melakukan hubungan seksual dengan sesama pria. Sejak 30 Juni 2007, 42\% dari kasus AIDS yang dilaporkan ditularkan melalui hubungan heteroseksual dan 53\% melalui penggunaan obat terlarang (Ditjen PP \& PL Kemenkes, 2012)

Pemerintah telah membuat komitmen serius untuk meningkatkan surveilans seperti meningkatkan rawatan, dukungan, dan pengobatan. Pada akhir 2005, pengobatan anti retroviral (ARV) telah disediakan untuk 10.000 dari perkiraan 15.000 ODHA yang membutuhkan pengobatan ini melalui program 3 by 5 . Di samping itu, berbagai upaya pencegahan juga dilakukan dengan peningkatan cakupan layanan, terutama akses jarum steril, pengobatan substitusi, tes dan konseling sukarela (VCT), perawatan medis, dan kelompok dukungan ( Komisi Penanggulangan AIDS, 2012)

Peran serta ODHA merupakan persoalan serius yang telah berulangkali dinyatakan para aktivis dan organisasi internasional. ODHA bukan obyek penanggulangan HIV dan AIDS melainkan subyeknya. Sebagai subyek, maka potensi ODHA untuk membagi pengalaman mereka secara bermakna dalam semua aspek penanggulangan harus diakui, dihargai, dan diberikan kesmpatan seluasluasnya. Pada banyak negara ODHA berperan dalam menambah pengetahuan medis dan teknis dalam memahami HIV dan ODHA memberikan sumbangan besar dalam mendukung sesama ODHA dan peranan mereka dalam penanggulangan HIV/AIDS di masyarakat semua ini menjadi contoh-contoh praktek nyata yang baik (best practices). 
Sumbangan ODHA di Indonesia dalam memberikan dukungan bagi ssesama ODHA telah lama diketahui dan menurut APN+ (2004) ini merupakan salah satu best practice dari GIPA (Greater Involvement of People with HIV/AIDS). Meskipun demikian, masih banyak ODHA yang belum terlibat dalam berbagai upaya penanggulangan - terutama dalam riset, monitoring dan evaluasi. Keterlibatan ODHA dalam bidang-bidang ini tentu akan memberikan sumbangan penting, karena banyak penelitian dan pengembangan program yang hanya dilakukan para pakar dan birokrat belum tentu dapat menyelami kehidupan ODHA. Keterlibatan ODHA akan membantu birokrat dan perencana program melakukan penyempurnaan (fine-tuning) penerapan hasil- hasil penelitian ODHA sehingga bisa tersusun program yang lebih peka terhadap kebutuhan ODHA (Komisi Penanggulangan AIDS, 2012).

Bentuk partisipasi masyarakat dalam mengatasi permasalahan kesehatan pada Penderita HIV/AIDS adalah adanya kelompok pendukung (support group). Dukungan sosial bagi ODHA sangat diperlukan selama lansia mampu memahami makna dukungan tersebut sebagai penopang hidupnya. ODHA yang memiliki masalah kesehatan baik fisik maupun psikis sangat membutuhkan bantuan dari orang lain untuk mengatasi masalah kesehatan yang dialaminya.

ODHA yang mengalami masalah fisik maupun psikologis sering mendapatkan stigma dan diskrimasi, yang membutuhkan bantuan untuk mengatasinya diantaranya melalui kegiatan promosi, pemeliharaan kesehatannya dalam tatanan keluarga maupun masyarakat melalui support group. Anderson dan McFarlane (2004) menyatakan studi membuktikan bahwa dukungan sosial dan support group sering dihubungkan dengan kesehatan dan orang yang mengalami keterbatasan fisik, sosial dan pikologis (Lapore, 1998) dan telah dibuktikan bahwa dukungan sosial dan support group meningkatkan kesehatan. Support group merupakan salah satu bentuk intervensi di komunitas melalui pendekatan proses kelompok (Anderson \& McFarlane, 2007).

Hasil penelitian didapatkan dukungan sosial dapat membantu individu untuk mengatasi masalahnya secara efektif, dukungan sosial juga dapat meningkatkan kesehatan fisik dan mental lansia (Bioschop \& Others, 2004; Erber 2005; Pruchno \& Rosenbaum 2003 dalam Santrock, 2006). Dukungan sosial berhubungan dengan gejala penyakit dan kemampuan untuk memenuhi kebutuhannya sendiri akan perawatan ( Cohen, Terasi \& homles, 1985 dalam Santrock, 2006). Antonucci 1990 dalam Santrock (1999) menyimpulkan bahwa interaksi sosial dengan orang-orang yang menyediakan dukungan sosial pada lansia, memberikan pandangan yang lebih positif mengenai dirinya.

Hasil penelitian support group caregiver pada penderita dimensia (2006) di Cuba mengidentifikasi $81 \%$ caregiver mendapatkan dukungan sosial dan emosional dan informasi yang berguna dari anggota kelompok lainnya. Sebagian besar caregiver juga melaporkan partisipasi, pengetahuan dan keterampilan mereka 
meningkat sebagai caregiver. Adanya support group dapat memberikan dukungan dalam bentuk berbagi pengalaman sehingga akan meningkatkan pengetahuan dan ketrampilan yang dimiliki oleh anggotanya untuk mengatasi masalah kesehatan anggota keluargannya.

Hasil penelitian Weis (2003) didapatkan support group pada lansia dengan penyakit kronik memberikan pengalaman yang berarti pada penderita dan dapat meningkatkan kesejahteraan psikologis, mengurangi kecemasan dan depresi, serta meningkatkan kualitas hidup, penanggulangan dan penyesuaian jiwa. Lansia yang menderita penyakit kronis sangat membutuhkan bantuan dari orang lain dan sekitarnya baik keluarganya, tetangganya, maupun masyarakat (Anderson \& McFarlane, 2004).

\section{METODE PENELITIAN}

Metode penelitian kualitatif dapat menggali, mengalisa dan menjelaskan fenomena dari pengalaman yang nyata secara rinci, luas dan mendalam. Adapun tiga langkah dalam fenomenologi deskriptif yaitu intuiting, analyzing dan describing. Dengan pendekatan indepth interview dengan anggota kelompok sebaya ODHA baik secara tertulis maupun lisan yang didasarkan pada klasifikasi dan pengelompokkan.

Tehnik pengambilan sampel dalam penelitian kualitatif menggunakan sampel bertujuan (purposive sampling) dengan kriteria tertentu yang tujuannya memperoleh sampel yang memenuhi kriteria tertentu dan berguna untuk menjamin kualitas sampel.

Sampel dalam penelitian ini 8 orang partisipan dan telah mencapai saturasi data. Penelitian ini dilakukan di vitory plus. Dalam penelitian ini menggunakan wawancara tidak terstruktur (wawancara mendalam) dan observasi dengan menggunakan field note sebagai alat pengumpulan data. Pada penelitian ini peneliti sebagai instrumen menguji kemampuan dalam melakukan wawancara. Peneliti menguji kehandalan alat pengumpulan data tersebut dalam latihan wawancara anggota kelompok sebaya orang HIV/AIDS yang mendampingi kehidupan ODHA. Uji coba dilakukan pada anggota kelompok sebaya ODHA diluar partisipan. Hasil uji coba terhadap satu orang partisipan telah memberikan gambaran awal mendampingi ODHA. Peneliti menggunakan alat bantu pengumpulan data dengan alat perekam MP4 yang berguna merekam hasil wawancara dengan partisipan.

Analisis data dalam penelitian ini dilakukan menyusun hasil wawancara dengan cara menstrankripkan hasil rekaman dalam bentuk verbatim, dan catatan lapangan yang didapatkan saat wawancara berlangsung berupa respon nonverbal yang diperlihatkan partisipan peneliti integrasikan dalam transkrip.

Langkah terakhir peneliti menuliskan semua hasil analisa dalam bentuk diskriptif naratif dari hasil penelitian. 


\section{HASIL DAN PEMBAHASAN}

Hasil dilakukan, yaitu pengalaman kelompok pendukung atau pendamping ODHA dalam menjalani hidup. Peneliti akan mendiskripsikan hasil penelitian ini yang meliputi dua bagian yaitu informasi umum tentang karakteristik partisipan, dan deskripsi hasil penelitian berupa pengelompokan tema yang muncul dari transkrip dan catatan lapangan yang didapatkan selama proses wawancara terdapat 15 tema

\section{Tema 1. Latar belakang menjadi pendamping ODHA.}

Pendamping ODHA memiliki karakteristik yang berbeda-beda tergantung pada permasalahan yang terjadi pada ODHA.

Membutuhkan teman untuk bercerita, ingin mambantu, merasa sebasib, membutuhkan teman, berbagi pengalaman, lebih bermanfaat.

Hal ini terungkap dari pernyataan partisipan sebagai berikut.

"...Ya saya butuh tempat untuk berbagi cerita ..." ( P2)

“...saya ingin membantu tema-teman yang terkena ODHA..." ( P3)

“...Karena saya merasa senasib dan sepenanggungan dengan teman-teman sebaya atau ODHA..." ( P4)

"...Aku pernah merasa akses layanan sendirian gak ketemu siapa siapa takut sendirian kayak gitu..." ( P5)

"....Membagi pengalaman hidup saya dengan teman-teman,..."(P4)

“...Setelah Positif HIV justru saya lebih bermanfaat..." ( P2)

\section{Tema 2 . Lama menjadi pendamping ODHA}

Hal ini terungkap dari penyataan partisipan sebagai berikut :

"... Selama 3 tahun ini kurang lebih...." (P1)

"...mulai bekerja dan menjadi pendukung sebaya tahun 2010 sampai hari ini..." (P4)

\section{Tema 3. Jumlah yang di dampingi oleh kelompok pendukung}

Partisipan mengungkapkan target setiap bulan, jumlah ODHA yang didampingi, jenis populasi yang didampingi oleh kelompok pendukung. Hal ini terungkap dari pernyataan partisispan sebagai berikut

"...Rata-rata target perbulannya ya 27-30 orang ..." ( P3)

"...Aku kemarin dapat 31 orang..." ( P5)

"..28 orang per bulan minimal dengan orang yang berbeda satu hari mungkin 1-2 orang.." (P7)

"...Saya sekitar mendamingi kurang lebihnya hampir 200 an_" (P1)

"...Aduh tidak terhitung sih kalau saya si ratusan..." (P3) 
"....Hetero dan LSL .. ada ibu rumah tangga tapi kebanyakan LSL..." (P1)

"...kita harus edukasi PMO pada TB ....edukasi pada SLS yang berbeda lagi..." ( P6)

\section{Tema 4. Bentuk Dukungan yang diberikan pada ODHA}

Bentuk-bentuk dukungan yang diberikan pada ODHA oleh kelompok pendamping sangat bervariasi tergantung kasus yang melatar belakangi terkenanya ODHA. Bentuk dukungan tersebut antara lain rujukan, Psikologis, informasional, edukasi, ketrampilan dan finansial, pemberdayaan pribadi, kegiatan postif dan akses pelayanan kesehatan, hal ini terungkap dari pernyataan partisipan sebagai berikut

"....banyaknya sih waria karena itu kan seperti saya..." (P1)

" ....membentuk dirinya sendiri dan menerima statusnya yang lain tergantung pribadi ..." ( P1)

"...Suportnya seperti perhatian..." (P5)

"...Saya kasih informasi saya datengi rumahnya, saya hubungi lewat bbm..." (P2)

“....Memberikkan informasi pemahaman mengenai HIV/AIDS itu apa..." ( P3)

"... kita kasih brosur-brosur KIE tentang HIV..." ( P1)

"...dengan keluaganya edukasi tentang kehidupan ODHA dan home care..." ( P5)

"...Ketrampilan untuk mendirikan usaha mandiri yang hasilkan uang ..." ( P1)

"...Modal usaha, dukungan finansial...." ( P1)

"....melibatkan dalam kegiatan kegiatan possitif..." ( P2)

"...Pemberdayaan pribadi,internal dan ekonomi..." ( P2)

"...membantu akses pelayanan dan memperkenalkan pada pelayanan kesehatan..." ( P3)

Sedangkan Bentuk dukungan pada anak-anak dengan HIV AIDS jaminan hidup, hidup, gizi dan apresiasi karya anak hal ini terungkap dari peryataan partisipan sebagai berikut.

"...Jadi pada jadi ada dana senilai 300 ribu perbulan tapi hanya 6 bulan..."(P2)

"....dibelikan susu, vitamin, buah-buahan, madu untuk anak-anak.." (P1)

"...kita mengapresiasi karya anak HIV dalam bentuk Mug dari lukisan anak.." ( P7)

\section{Tema 5. Kendala dalam proses pendampingan}

Dalam proses pendampingan kelompok pendukung biasanya juga mengalami berbagai masalah yang dapat menghambat. Masalah yang sering dirasakan menghambat adalah tertutup, marah, drop out, menolak, rewel. Hal ini terungkap dari pernyetaan partisipan sebagai berikut.

"...yang sering kali kita temukan klien masih menutup statusnya terhadap keluarga.." ( P1)

“...dimarah-marahi dan dimaki-maki oleh keluarganya..." ( P4) 
"... Kendala ini teman-teman udah lama tepai karena merasa sehat dan CD 4 tinggi terus berhenti minum ARV..." (P4)

"...Kadang ada klien yang menolak kita dampingi karena putus asa duluan..." ( P7)

"...Kadang ada klien yang menolak kita dampingi karena putus asa duluan..." ( P8)

\section{Tema 6. Manfaat dukungan sebaya Bagi ODHA}

Kemafaatan adanya kelompok dukungan sebaya bagi ODHA sangat dirasakan karena ODHA dapat menjadi beraktifitas kembali, berdaya, mandiri, hidup normal dan percaya diri. Kemanfaatan secara nyata terungkap dalam beberapa sub tema sebagai berikut.

"...Mereka kembali bekerja atau kembali kuliah..." ( P2)

"...jadi kita membantu teman-teman yang belum berdaya menjadi lebih berdaya dalam hidupnya..." ( P4)

"...Adapun pendampingannya temen-temen juga semuanya jadi mandiri..." ( P5)

"...mereka itu jadi percaya diri itu..." (P5)

\section{Tema 7. Sikap Pendamping selama mendampingi ODHA}

Sikap dalam menghadapi ODHA ketika mendampingi ODHA baik di rumah sakit dan komunitas adalah sabar, ikhlas, ramah, memiliki hati, tlaten dan kadang galak. Adapun Sub tema sikap dapam melakukan pendampingan terhadap ODHA terungkap dari pernyataan partisipan.

"...mengelola kesabaran menjadi sangat penting pagi kita..." (P8)

"...Kita harus ramah dan memberikan informasi ..." (P2)

"... menjadi pendukung sebaya itu harus dari hati karena klu gak punya hati kita nakal..." (P2)

"...Harus ikklas dan tidak berharap mendapatkan uang dari yang didampingi..." (P2)

"...lebih tlaten lagi ngadepinya..." ( P8)

"...Aku terkenal kelompok pendukung sebaya paling galak karena suka marahin mereka jika tidak minum obat..." ( P5)

\section{Tema 8. Perasaan menjadi pendamping ODHA}

Kelompok pendamping ketika menjalankan tugasnya menjadi penjangkau di layanan tatanan kesehatan dan komunitas akan merasakan pahit manisnya mendampingi hidup ODHA sampai mandiri. Adapun perasaaan-perasaan tersebut antara lain menyenangkan, dan puas hal tersebut terungkap dari pernyetaan partisipan sebagi berikut.

"...Iya mennyennagkan kalu kerja disini ketawa aja kerjaannya..."

"....ya menurut saya kepuasan tersendiri buat saya...." (P2) 
"...Kita dampingin, mereka sudah sehat, gemuk sudah berjalan dan ada yang menikah lagi rasanya luar biasa..." (P4)

\section{Tema 9. Kegiatan ODHA dalam proses pendampingan}

Aktivitas ODHA dalam proses pendampingan kelompok dukungan sebaya yang dirintis selama ini sangat bervariasi. Tujuannya ODHA dapat berkumpul dengan teman-temannya dan tidak merasakan penderitaan hidupnya sendiri, selain itu juga meningkatkan produktivitas sebagai besar ODHA. Kegiatan yang telah dilakukan ODHA bersama pendamping adalah pelatihan, dan pemberdayaan ekonomi hal ini terungkap dari pernyataan pertisipan sebagi berikut.

".....mengadakan pelatihan pendukung dalam mendapingi ODHA..." ( P1)

" ...mendapatkan program sembako aku daftarin bagi ekonomi yang gak mampu.." ( P7)

\section{Tema 10. Kebutuhan Kelompok pendukung}

Anggota kelompok pendukung sebaya selama melakukan aktivitas pendampingan dengan ODHA membutuhkan bekal untuk dirinya dalam meningkatkan kapasitasnya sebagai seorang pendamping. Kebutuhan-kebutuhan pendamping untuk meningkatkan kapasitas dirinya terungkap dalam beberapa sub tema antara lain ketrampilan, role model, berfikir positif, materi dan modul peltihan. Hal ini terungkap dari pernyataan partisipan sebagi berikut.

"...bahasa, komunikasi, wawasan, pengalaman..."

"...Seorang pendukung sebaya itu harus menjadi roll mode untuk yang lain..."

"...Mindset pola pikir kita harus berubah harus selalu positif atau kata orang bahasa gaulnya enjoy...." ( P1)

"...Modul misalnya edukator yang harus dipelajari sebelum ke pasien.." (P3)

"...cara berkomunikasi dengan paien itu seperti apa itu ada pelatihannya..."

"...yang jelas sebagai pendukung sebaya itu harus paham betul apa itu HIV/AIDS..." ( P4)

\section{Tema 11. Kegiatan antar kelompok pendukung}

Kegiatan-kegiatan yang dilakukan pada kelompok pendukung sangat banyak dan biasanya saling mendukung antara anggota kelompok satu dengan yang lainnya terutama jika tidak dapat menyelesaikan permasalahan pada ODHA yang didimpinginya saat ini dan sesuai dengan kebutuhan mereka. Kegiatan tersebut meliputi antara lain belajar bersama, saling membantu dan saling mendukung, study "...bersama teman-teman study club, publik speaking biar berani ngomong di depan orang banyak." ( P2) 
"...Kalau saya ada kesulitan berkomunikasi dengan mereka dan saling membantu..."(P3)

"...kita harus saling tolong menolong saling membantu antara pendamping satu dengan yang lainnya..." (P2)

"...Ada study Club sama rapat koordinasi..." (P5)

“...Paling seling mengadakan rapat koordinasi ya cuman sebulan sekali atau 2 minggu sekali lah.." ( P5)

\section{Tema 12. Waktu Pendampingan}

Berdasarkan hasil wawancara yang dilakukan dengan partisipan terdapat tema yang berkaitan dengan waktu melakukan pendampingan baik di rumah sakit, puskesmas ataupun dengan keluarganya ODHA di rumah. Hal ini terungkap pernyataan partisipan sebagai berikut.

“....Paling seling mengadakan rapat koordinasi ya cuman sebulan sekali atau 2 minggu sekali lah.." ( P3)

" ....dari layanan kita itu setiap hari 4 jam stand by ...."( P7).

\section{Tema 13. Prinsip pendampingan}

Prinsip pendampingan yang dilakukan oleh kelompok pendukung sebagai upaya terhadap penenggulangan HIV/AIDS terdapat pada sub tema membuka status, informasi HIV/AIDS, mengkases pelayanan kesehatan, tidak menularkan kepada orang lain dan beripilaku positif. Hal ini terungkap dari pernyataan partisipan sebagi berikut

"...Pokonyak sengaja kita open status karena kalu gak gaka gini mereka gak percaya...." ( P5)

"...saya akan membuka status dan itu sudah saya siapkan..." ( P7)

"...dukung memberi informasi HIV/AIDS yang benar ada 9 buku..."( P2)

"....mereka mau mengakses pelayanan kesehatan..."( P2)

"...HIV stop sampai disini/tidak menularkan virus HIV/AIDS kepada orang lain... ( P2)

"...melakukan kegiatan-kegiatan yang positif..."(P2)

\section{Tema 14. Pelayanan kesehatan}

Tempat pelayanan yang sering digunkan untuk kelompok pendukung dalam melakukan pendampingan terhadap ODHA terdapat beberapa sub tema; puskesmas, lapas, rumah sakit dan Badan Narkotika Nasional. Hal tersebut terungkap dari pernyataan partisipan sebagi berikut.

"...Puskesmas Gedong tengen itu dari keplaa puskesmas samapi anak buahnya semua care..." (P4)

"...on call puskesesmas kota sama puskesmas sleman..." ( P5)

"...Pernah saya dampingi seorang warga binaan lapas di jogja.." (P5) 
"...Ya Sardjito, rumah sakit morangan, terus PKU Bethesda dan pantirapih..." ( P1)

"...saya stran by di klinik layanan CST RSUD Wates, RSUD bantul dan Sarjito...( P3)

"...kalau saya kebetulan di RSUD bantul dan Sarjito tugasnya..." (P7)

"...Saya juga bekerjasama dengan betesdha, panti rapih, PKU muhammmadiyah..." ( P7)

"...Kita juga di kantor, konselor adiksi obat BNNK..." (P7)

\section{Tema 15 Harapan terhadap pelayanan Kesehatan}

Anggota kelompok penjangkau memiliki harapan terhadap tenaga pelayanan kesehatan sebagai garda depan terhadap pelayanan kepada ODHA. Adapun tema yang ditemukan dalam penelitian ini terhadap pelayanan kesehatan adalah tidak terjadi diskriminasi pelayanan kesehatan, tidak ada stigma, tidak pingin tahu dan menghargai klien. Hal ini terungkap dari pernyataan klien.

"...Itu supaya kalau di pelayanan kesehatan tidak diskriminasi...." ( P4)

"...Odha oleh tenaga kesehatan di identikan dengan kaum pendosa.." (P2)

" ...Suster dirumah sakit itu kepo nanya ke pasiennya kena HIV dari mana?" (P2

"...Kita punya Hak yang sama dan diperlakukan sama tidak ada yang istimewakan dan tidak diperlakukan buruk lho bu..."( P2)

"...yang pasti kita tidak butuh dihakimi, surga neraka itu urusan Tuhan..." P3)

"..bisa menjaga kode etik apalagi pasien HIV/AIDS walaupun masyarakat paham masih agak-agak..."( P7)

Kelompok pendamping ODHA, yang sering dikenal dengan istilah kelompok pendukung sebaya (KDS) merupakan kelompok yang terdiri dari orangorang yang mempunyai permasalahan atau situasi yang sama, berfungsi unutk memberikan dukungan satu dengan lainnya (Setiawan, 2011) Berbagai hal yang melatar belakangi seseorang menjadi pendamping atau kelompok pendukung sebaya (KDS) ODHA adalah pengalaman pribadi yang pernah dialami, panggilan jiwa untuk menyelamatkan orang lain setelah merasakan sendiri bagaimana menjadi seorang ODHA dan keinginan menjadi role model agar ODHA lain mencontoh atau mengikuti dirinya, ingin membagikan pengalaman, ingin membantu dan merasa lebih bermanfaat bagi orang lain.

Kelompok pendamping ini sangat diperlukan bahkan memiliki peran yang bermakna dalam mutu hidup ODHA. ODHA yang mendapatkan dukungan sebaya berpengaruh pada tingkat kepercayaan diri, pengetahuan HIV, akses layanan HIV, perilaku pencegahan HIV, dan kegiatan positif yang lebih tinggi dibandingkan ODHA yang tidak mendapatkan dukungan sebaya (Handayani, 2011). Hal ini juga diperkuat oleh pendapat Setiawan (2011) dalam penelitiannya yang berjudul 
"Testimoni Melalui KDS (Kelompok Pendukung Sebaya), Hapuskan Sekat Terhadap ODHA", menyebutkan bahwa kelompok pendukung dibentuk dengan tujuan untuk memberikan dukungan memberikan dukungan berupa informasi, masukan, pengalaman dan hal lain yang dapat membantu ODHA menjadi mandiri dan meningkatkan kualitas hidupnya dan telah terbutki secara statistik bahwa hubungan yang signifikan antara peran KDS dengan kepatuhan minum obat pada ODHA, nilai $\mathrm{p}=0.000$ pada penelitian yang berjudul Peran Kelompok Pendukung Sebaya (KDS) dan Kepatuhan Minum Obat Pada ODHA (Yuswanto, Wahyuni dan Pitoyo, 2015).

Dukungan moral dan semangat ini sangat dibutuhkan oleh ODHA sebab ketika dia tahu dirinya terinfeksi HIV maka muncul pergolakan batin besar dalam dirinya dimana dia akan dihadapkan dengan dirinya sendiri yang lalu memunculkan berbagai macam sikap seperti penyangkalan jika ia terinfeksi HIV, marah dan sedih. kelompok inilah yang diharapkan bisa mentransformasikan sikap-sikap ini menjadi sebuah sikap penerimaan diri sehingga ODHA tersebut bisa tetap sehat, tetap produktif dan yang paling penting adalah dia tidak merasa sendiri.

Sikap empati seperti inilah yang selama ini jarang mereka dapatkan dari orang-orang lain yang tidak terinfeksi HIV baik keluarganya sendiri, temantemannya maupun masyarakat luas. Kelompok Dukungan Sebaya yang memainkan peran penting di awal-awal ini. Setelah sikap penerimaan ini terbangun, kelompok dukungan sebaya kemudian menjadi sebuah wadah untuk berbagi akses. Baik akses informasi maupun akses rujukan layanan. Seorang ODHA baru umumnya merasa buta akan kondisi tubuhnya sendiri pasca dia terinfeksi HIV. untuk meminta informasi ke dokter pun kadang muncul keengganan selain dikarenakan masih sedikitnya dokter yang kompeten soal HIV, mahalnya biaya sampai sikap dokter dan pemberi layanan kesehatan sendiri yang kerap kali masih memunculkan stigma dan diskriminasi bagi ODHA tersebut. Di KDS, ODHA bisa berbagi informasi perawatan dan pengobatan serta saling memberikan support guna memotivasi agar tetap hidup sehat

Pengalaman dalam mendampingan yang telah lebih dari 5 tahun ini memberikan gambaran bahwa pendamping serius dalam membantu ODHA untuk menjadi penyintas atau survivor. Seseorang yang telah memiliki banyak pengalaman akan menjadi mereka lebih mudah beradaptasi atau menerima keadaan ODHA dengan berbagai permaklumannya, memiliki komitmen yang tinggi untuk membantu, memiliki motivasi dan inspirasi yang tinggi dan memiliki perspektif yang luas tentang HIV/AIDS dan ODHA (www. wedaran.com).

Sebagian informan memiliki pengalaman kurang lebih 3 tahun, hal ini menunjukkan bahwa semakin tahun banyak orang yang berkomitmen menjadi kelompok penduduk ODHA. Semakin bertambahnya kelompok ini juga seiring dengan jumlah ODHA di Indonesia. Hasil penelitian Yuswanto, Wahyuni dan Pitoyo (2015) menyebutkan bahwa pengalaman menjadi ODHA antara 1-3 tahun 
sebanyak $53 \%$, artinya selalu ada ODHA baru dan setelah menjadi ODHA kemudian berkomitmen menjadi pendamping, sehingga ditemukan jumlah pendamping semakin bertambah yang ditunjukkan dengan pengalaman kurang dari 1-3 tahun tersebut.

Jumlah ODHA yang didampingi oleh KDS setiap hari sangat bervariasi hal tersebut menunjukkan bahawa data HIV/AIDS di Indonesia semakin meningkat. Hal tersebut senanda dengan pendapat HIV \& AIDS di Indonesia sudah secara resmi dilaporkan sejak 19 tahun lalu. Selama kurun waktu itu, kecenderungannya tidak pernah berkurang atau berhenti. Gambar 1 menunjukkan bahwa kecenderungannya terus meningkat. Walau jumlah kasus yang dilaporkan masih di bawah 6.000 kasus estimasi terhadap jumlah ODHA sebenarnya berkisar 53.000 sampai 180.0001 orang (WHO/UNAIDS, 2005). Sebagian besar adalah laki-laki $(82 \%)$ dan selama enam tahun terakhir laporan kasus didominasi oleh infeksi dari kalangan IDU. Sama seperti kecenderungan di beberapa negara Asia lainnya (Cina, Thailand, Vietnam) HIV/AIDS di Indonesia adalah masalah generasi muda. Kelompok usia tersebut adalah kelompok produktif dan berpendidikan cukup tinggi. Karena sifatnya yang produktif itu maka ODHA sangat dibutuhkan negara berkembang (MAP, 2004; KPA, 2003). Jika kebutuhan kesehatan ODHA tidak diperhatikan, maka kualitas hidup ODHA akan menurun drastis sejalan dengan perjalanan penyakit tersebut. Artinya, ketika infeksi itu menguasai tubuh ODHA, maka ODHA akan dirundung sakit dan tidak mungkin dapat berkontribusi pada keluarga dan masyarakatnya secara efektif.

Dukungan emosisional ini sangat diperlukan ODHA, terutama dukungan dari masyarakat. Perlakuan diskriminasi dari masyarakat yang diterima ODHA membuat ODHA semakin stress dan anakn membawa dampak yang lebih buruk pada ODHA, dimana perkembangan penyakit justru akan semakin cepat dan memperburuk kondisi ODHA.

Dukungan penghargaan, yaitu terjadi apabila ada ekspresi penilaian yang positif terhadap individu. Cohen dan Wills mengemukakan bahwa dukungan penghargaan ini merupakan informasi yang diberikan pada seseorang bahwa dia dihargai dan diterima, diakui keberadaannya dan rasa dimiliki dan dicintai orang lain. Harga diri seseorang dapat ditingkatkan dengan cara mengkomunikasikan kepadanya bahwa dia bernilai dan diterima meskipun tidak luput dari kesalahan. ODHA membutuhkan dukungan penghargaan berupa penerimaan dan penilaian positif dari masyarakat, walaupun adanya stigma yang berkembang dimasyarat yang menganggap bahwa penyakit HIV/AIDS adalah penyakit "kutukan" yang disebabkan oleh kesalahan individu berupa perilaku seksual menyimpang ataupun pengguna narkoba. Munculnya stigma ini dikarenakan 2 hal yaitu adanya salah presepsi atas cara penularan HIV/AIDS dan adanya anggapan bahwa semua ODHA adalah orang tercela. 
Dukungan integritas sosial, yaitu perasaan individu sebagai bagian dari suatu kelompok. Cohen dan Will berpendapat bahwa dukungan ini dapat berupa menghabiskan waktu bersama-sama dengan orang lain dalam aktifitas rekreasional dan waktu senggang. Dukungan ini dapat mengurangi stress dengan memenuhi kebutuhan afiliasi dan kontak dengan orang lain, dengan membantu mengalihkan perhatian seseorang dari kecemasan terhadap masalah, atau dengan memfasilitasi suatu suasana hati yang positif. Menurut Barrerra dan Ainley (dalam Oxford) menggambarkan dukungan ini termasuk didalamnya membuat lelucon, membicarakan minat, berorganisasi dan melakukan aktifitas yang menciptakan perasaan senang/kesenangan.

Kendala dalam melakukan pendampingan selain berasal dari diri ODHA juga bersala dari keluarga. Odha kadang kala tidak menyadari bahawa penyakit yang dideritanya jika tidak mendapatkan terapi secara efektif akan sangat berbahaya bagi tubunya. Odaha yang masih menutup diri kepada orang lain, merupakan sebuah kendala utama dalam proses melakukan pendampingan. Demikian juga keluarga yang tidak mau menerima kondisi klien dan kadang kala dianggap KDS akan membuat masalah baru dalam kehidupan ODHA.

Manfaat adanya KDS adalah Punya Kepercayaan Diri. Stigma yang terkait dengan HIV sangat mungkin mempengaruhi kesehatan fisik dan mental. Dalam satu penelitian di China, orang dengan HIV melaporkan stigma yang membuat mereka merasa tertekan, cemas, sedih, tidak bernilai dan bersalah, dan bahkan menimbulkan gangguan kejiwaan. Sumbangan ODHA di Indonesia dalam memberikan dukungan bagi sesama ODHA telah lama diketahui dan menurut APN+ (2004) ini merupakan salah satu best practice dari GIPA (Greater Involvement of People with HIV/AIDS). Meskipun demikian, masih banyak ODHA yang belum terlibat dalam berbagai upaya penanggulangan - terutama dalam riset, monitoring dan evaluasi. Keterlibatan ODHA dalam bidang-bidang ini tentu akan memberikan sumbangan penting, karena banyak penelitian dan pengembangan program. yang hanya dilakukan para pakar dan birokrat belum tentu dapat menyelami kehidupan ODHA. Keterlibatan ODHA akan membantu birokrat dan perencana program melakukan penyempurnaan (fine-tuning) penerapan hasil- hasil penelitian ODHA sehingga bisa tersusun program yang lebih peka terhadap kebutuhan ODHA.

Perawatan di RS banyak mendatangkan masalah bagi ODHA. Ketika ada yang harus dirawat di RS, maka ODHA yang tidak mempunyai pendamping (keluarga maupun LSM) akan mengalami kesulitan mengikuti prosedur karena tidak memiliki informasi mengenai prosesnya. Selain itu ODHA yang tanpa pendamping juga tidak akan mendapat layanan optimal karena sebagian RS mengharapkan pendamping/keluargalah yang mengurus berbagai hal keperluan pasien (termasuk penyediaan obat). ODHA yang punya pendamping atau pengalaman mengakses layanan pun masih dapat mengalami masalah ketika 
menjalani perawatan. Ada yang mengeluh tidak mendapat layanan karena statusnya sebagai ODHA, ada yang dipindah-pindah dari satu petugas/perawat ke petugas lainnya, tidak mendapat perawatan yang layak, didiskriminasi dan diperlakukan dengan tidak baik oleh perawat atau petugas kesehatan lainnya. Perawatan bagi ODHA masih kurang baik dan tidak memenuhi syarat di beberapa tempat.

Layanan diskriminatif di pusat-pusat layanan kesehatan seperti RS tidak hanya terjadi karena status sebagai ODHA tetapi juga sebagai orang yang terpaksa menggunakan JPS, askes, gakin, dll. FGD banyak mengung- kapkan terjadinya pembedaan layanan antara "yang miskin" (pengguna JPS) dan "yang tidak miskin" sementara banyak pasien ODHA berstatus kurang mampu.

Sikap pendamping selama memberikan dukungan pada ODHA yang dianggap penting oleh informan antara lain sabar, ramah, menggunakan hati, ikhlas dan telaten. Namun demikian, sikap tegas dan kadang dipersepsi galak pun harus dilakukan dengan tujuan agar ODHA disiplin dalam menjalani perawatan dan pengobatan.

Sikap empati atau menggunakan hati seperti inilah yang selama ini jarang mereka dapatkan dari orang-orang lain yang tidak terinfeksi HIV baik keluarganya sendiri, teman-temannya maupun masyarakat luas. Kelompok Dukungan Sebaya yang memainkan peran penting di awal-awal ini. Setelah sikap penerimaan ini terbangun, kelompok dukungan sebaya kemudian menjadi sebuah wadah untuk berbagi akses. Baik akses informasi maupun akses rujukan layanan (Anonim, 2012 dalam www.odhaberhaksehat.org, 30 Oktober 2016).

Pelatihan untuk menyiapakan pendampingan yang dilakukan antara lain pelatihan public speaking, tujuannya untuk melatih ODHA dan OHIDHA untuk bisa trampil berbicara di depan umum. Yang kedua adalah pelatihan pembentukan KDS, bertujuan untuk mempersiapkan ODHA dan OHIDHA untuk menjadi motor dalam pembentukan KDS di setiap wilayah dan kelompok resiko. Yang ketiga adalah pelatihan pendidik pengobatan (threatment educator) yang bertujuan untuk melatih mereka untuk menjadi pendamping pengobatan terhadap ODHA yang baru saja memulaithreatment. Dan yang terakhir adalah memperlengkapi ODHA yang baru mengetahui status HIV nya dalam pertemuan ODHA provinsi, Kemudian adanya pemberdayaan psikososial, ekonomi dan sosial terhadap ODHA, serta stigma dan diskriminasi HIV mulai terkikis (Utama dan Andika, 2015).

Gerakan orang tua asuh ; biaya kesehatan anak, biaya pendidikan anak, Lingkungan ramah anak. Kegiatan-kegiatan yang dilakukan pada kelompok pendukung sangat banyak dan biasanya saling mendukung antara anggota kelompok satu dengan yang lainnya terutama jika tidak dapat menyelesaikan permasalahan pada ODHA yang didimpinginya saat ini dan sesuai dengan kebutuhan mereka. Study club, sebagai wahana sharing menjadi kebutuhan karena kompleknya permasalahan yang dihadapi ODHA dalam kehidupan sehari-hari. Setiap minggu kelompok pendamping melakukan rapat koordinasi untuk 
memecahkan masalah dan sekaligus melaporkan terhadap semua aktivitas yang dilakukan selama proses pendampingan. Pada setiap pertemuan yang dilakukan hari selasa dan jumat anggota kelompok pendukung melakukan koordinasi terhadap permasalahan yang terjadi pada klien yang didampinginya dan mereka biasanya saling membantu dan saling mendukung terhadap masalah dan kendala yang dihadapinya.

Pilar pertama ini diukur dari tiga hal yaitu penerimaan Odha terhadap status HIV positif, kenyamanan Odha membuka status terhadap orang terdekat, dan kenyamanan Odha berinteraksi dan berkomunikasi.

Hal yang pertama, penerimaan Odha terhadap status HIV positif diukur dari enam pertanyaan, yaitu perasaan rendah diri karena status HIV, status HIV mengganggu sikap dan perilaku, perasaan dan keinginan untuk menjauhi orang lain, kebiasaan memisahkan barang yang digunakan untuk tidak digunakan oleh orang lain serta memiliki kecemasan, kekhawatiran, ketakutan dalam menjalani kehidupan dengan status HIV.

Odha yang menyatakan tidak memiliki perasaan rendah diri karena status HIV, hampir seimbang dengan Odha yang menyatakan memiliki perasaan rendah diri. Odha lebih banyak yang menyatakan status HIV tidak mengganggu sikap dan perilakunya, dan hanya sedikit yang menyatakan terganggu karena status HIV. Sebagian besar Odha lebih banyak yang tidak memiliki perasaan dan keinginan untuk menjauhi orang lain, dan juga sebagian besar Odha paling banyak tidak berperilaku memisahkan barang yang digunakan untuk tidak digunakan oleh orang lain. Odha yang memiliki kecemasan dalam menjalani kehidupan dengan status HIV mencapai $70 \%$ dengan kadar kecemasan yang berbeda, dan kurang dari $40 \%$ yang menyatakan tidak memiliki kecemasan. Hasil ini mengalami missing value antara $2,3-3,3 \%$.

Odha paling banyak yang menyatakan tidak nyaman jika berkomunikasi dan berinteraksi pada tetangga, dan Odha paling banyak menyatakan nyaman pada teman sebaya dan keluarga. Hasil total skor pada poin yang mengukur skor menerima status HIV, membuka status HIV, dan berinteraksi serta berkomunikasi memiliki distribusi tidak normal sehingga cut off point dalam pengelompokan total skor berdasarkan median. Odha lebih banyak yang menerima status HIV dengan positif, Odha lebih banyak yang memiliki kenyamanan untuk memberitahukan status HIV, dan kenyamanan berkomunikasi dan berinteraksi.

Pilar kedua dalam mutu hidup Odha adalah pengetahuan HIV/AIDS. Pengetahuan HIV/AIDS diukur dengan 11 pertanyaan tentang pengetahuan dasar HIV/AIDS dan pengetahuan tentang pengobatan HIV/AIDS. Pertanyaan yang banyak dijawab benar oleh Odha adalah tentang pengertian HIV, bagian darah yang diserang oleh virus HIV, obat yang dapat menghambat perkembangan HIV dalam darah, cairan yang tidak dapat terinfeksi HIV, dan cara terinveksi HIV. Pertanyaan 
yang paling rendah dijawab benar oleh Odha adalah pertanyaan tentang pengertian infeksi oportunistik.

Odha yang memiliki pengetahuan HIV dengan baik lebih banyak pada Odha yang berumur 30 - 39 tahun. Untuk pengetahuan HIV yang baik lebih banyak dimiliki oleh Odha laki-laki daripada Odha perempuan. Odha yang berpendidikan di atas SMA lebih banyak memiliki pengetahuan HIV yang baik daripada Odha yang tidak lulus SMA. Odha penasun memiliki pengetahuan yang lebih baik daripada Odha populasi risiko lainnya.

Pilar ketiga ini, menggambarkan Odha mendapatkan layanan dukungan mental, pengobatan dan perawatan. Selain hal itu, bagian ini juga menggambarkan pengetahuan Odha tentang lokasi Rumah Sakit Rujukan, pemanfaatan layanan Pap smear, pemanfaatan rawat inap serta kemudahan mendapatkan perawatan dokter, obat ARV, layanan Pap smear, layanan pengobatan IMS, dan layanan rawat inap.

Odha yang mendapatkan layanan dukungan mental paling banyak dari kelompok dukung sebaya, dokter, dan keluarga. Odha paling sedikit menjawab mendapatkan dukungan mental dari tetangga. Dukungan mental dari pasangan lebih rendah persentasenya daripada dukungan mental dari LSM, keluarga, dokter, dan kelompok dukungan sebaya. Odha paling banyak mengetahui beberapa Rumah Sakit rujukan atau puskesmas yang memberikan layanan pengobatan infeksi oportunistik dan ARV. Odha yang tidak mengetahui hanya kecil persentasenya. Odha Laki-laki paling banyak yang menyatakan mengetahui semua RS rujukan untuk HIV/AIDS, sedangkan Odha perempuan paling banyak menyatakan tidak mengetahui RS rujukan. Odha penasun dan Odha waria paling banyak menyatakan tahu semua RS rujukan. Sedangkan Odha IRT, Odha pelanggan seks, Odha pekerja seks, Odha pasangan risti, paling banyak menyatakan tidak tahu RS rujukan.

Odha yang pernah dirawat inap di Rumah Sakit paling banyak menyatakan mudah mendapatkan pelayanan rawat inap di Rumah Sakit. Odha yang membutuhkan layanan pemeriksaan dokter, lebih banyak yang menyatakan adanya kemudahan mendapatkan layanan pemeriksaan dokter sedangkan Odha yang menyatakan sangat sulit dan sulit dalam mendapatkan layanan pemeriksaan dokter hanya sedikit.

Pilar keempat menggambarkan perilaku pencegahan terinfeksi HIV yang dilakukan oleh Odha. Perilaku pencegahan terinfeksi HIV antara lain menggunakan kondom saat berhubungan seksual, menggunakan jarum suntik steril, menggunakan layanan program pencegahan terinfeksi HIV dari ibu ke bayi, tidak mendonorkan darah, serta memberitahukan status HIV saat mencabut gigi dan melakukan operasi. Selain itu juga menggambarkan akses mendapatkan kondom, jarum suntik steril, dan mendapatkan layanan PMTCT.

Odha yang melakukan hubungan seks setelah mengetahui status HIV, paling banyak yang selalu menggunakan kondom setiap berhubungan seks. Namun masih ada Odha yang tidak pernah menggunakan kondom saat berhubungan 
seksual. Odha yang melakukan hubungan seksual 6 bulan terakhir paling banyak menyatakan selalu menggunakan kondom saat berhubungan seksual. Berdasarkan jenis kelamin, Odha laki-laki lebih banyak yang selalu menggunakan kondom daripada Odha perempuan. Odha dari kelompok risiko pekerja seks, waria, dan gay lebih banyak yang selalu menggunakan kondom daripada kelompok risiko yang lain. Odha yang memiliki tingkat pendidikan tamat SMA dan Odha yang memiliki tingkat pengeluaran yang tinggi lebih banyak yang selalu menggunakan kondom.

Pada pilar ke lima Odha yang bekerja pada 12 bulan terakhir, lebih banyak daripada yang tidak bekerja. Odha yang bekerja juga lebih banyak laki-laki daripada perempuan. Odha yang tidak bekerja lebih banyak pada kelompok ibu rumah tangga dan pasangan risiko tinggi. Odha lebih banyak yang tidak melakukan kegiatan hobi pada 12 bulan terakhir. Odha yang masih menjalani hobi setelah mengetahui status, lebih banyak pada Odha yang memiliki pendidikan tinggi daripada yang berpendidikan rendah.

Layanan diskriminatif di pusat-pusat layanan kesehatan seperti RS tidak hanya terjadi karena status sebagai ODHA tetapi juga sebagai orang yang terpaksa menggunakan JPS, askes, gakin, dll. FGD banyak mengung- kapkan terjadinya pembedaan layanan antara "yang miskin" (pengguna JPS) dan "yang tidak miskin" sementara banyak pasien ODHA berstatus kurang mampu.

Pelanggaran terhadap prosedur standarise.j(SOP) dan Universal Precautions (UP) dimanaichetpetugas kesehatan tidak mengikuti prosedur penangan HIV dengan benar (tidak menggunakan sarung tangan, tidak mencuci tangan) dll. Selain itu FGD juga mengungkap kasus-kasus pelanggaran SOP dan etika oleh petugas kesehatan, antara lain tidak dilakukan konseling sebelum test, tidak dijelaskannya efek samping dari obat atau terapi, petugas kesehatan melakukan pelanggaran terhadap prosedur standart (SOP dan UP). Kerahasiaan pasien juga tidak selamanya terjaga baik oleh petugas laboratorium maupun di ruang-ruang konseling.

Keterbatasan informasi, pengetahuan dan keterampilan dari para petugas kesehatan, termasuk diantaranya beberapa dokter menyangkut penanganan HIV/AIDS. Hal ini terungkap ketika ODHA mendapatkan informasi dan penanganan yang berbeda-beda antar petugas kesehatan.Ketakutan dan salah penanganan dari petugas kesehatan juga menunjukan masih kurangnya informasi tentang HIV/AIDS. Penanganan yang tidak berkesinambungan dan oleh petugas/dokter/konselor yang berbeda-beda juga merupakan salah satu keluhan. Masalah tidak tuntas karena petugas yang menangani kasus ODHA bisa bergantiganti.

\section{KESIMPULAN}

1. Anggota kelompok pendamping memiliki motivasi dan latar belakang yang kuat dalam memberikan dukungan ODHA agar dapat menjalani hidup sebagai 
penyintas, yakni adalah pengalaman pribadi yang pernah dialami, panggilan jiwa untuk menyelamatkan orang lain setelah merasakan sendiri bagaimana menjadi seorang ODHA dan keinginan menjadi role model agar ODHA lain mencontoh atau mengikuti dirinya, ingin membagikan pengalaman, ingin membantu dan merasa lebih bermanfaat bagi orang lain.

2. Bentuk dukungan yang diberikan oleh para pendamping di Yogyakarta adalah dukungan yang langsung diberikan kepada ODHA maupun anak-anak yang terlahir dari ODHA. Dari hasil penelitian menunjukkan bahwa secara garis besar dukungan yang diberikan oleh pendamping ada 5 jenis yakni dukungan finansial, informasional, emosional atau psikososial dan dukungan sosial.

3. Beberapa kendala umum yang dihadapi para pendamping ODHA di Yogyakarta ini berupa sikap tertutup, menolak, marah, putus obat, serta banyak yang mengeluh dengan berbagai alasan. Beberapa kendala ini benar ditemukan, bagi ODHA yang baru mengetahui status HIV-nya, intensitas emosi ODHA sangat tinggi. Mereka kecewa, marah, frustasi, ingin bunuh diri, merasa putus asa, stress dan down.

4. Manfaat yang diperoleh ODHA melalui kegiatan pendampingan, yakni merasa berdaya kembali setelah merasa terpuruk karena diagnosis HIV-AIDS, menjadi bercaya diri, mulai berktivitas sendiri sehingga muncul rasa kemandirian dalam kehidupan sehari-hari.

5. Sikap pendamping selama memberikan dukungan pada ODHA yang dianggap penting oleh informan antara lain sabar, ramah, menggunakan hati, ikhlas dan telaten. Namun demikian, sikap tegas dan kadang dipersepsi galak pun harus dilakukan dengan tujuan agar ODHA disiplin dalam menjalani perawatan dan pengobatan. Sikap empati atau menggunakan hati seperti inilah yang selama ini jarang mereka dapatkan dari orang-orang lain yang tidak terinfeksi HIV baik keluarganya sendiri, teman-temannya maupun masyarakat luas.

6. Selama memberikan dukungan kelompok ini telah merasakan sangat senang dengan pekerjaan ini dan merasakan ada kepuasan batin karena bisa menolong orang lain.

7. Hasil penelitian ini menunjukka bahwa kegiatan yang dirasakan oleh ODHA antara lain pelatihan yang membantu mereka terampil dan mampu mandiri dengan ketrampilan itu, sehingga mereka dapat mencari nafkah seperti orang lain pada umumnya. Kegiatan ODHA yang memberikan manfaat baik secara mental maupun material ini sangat mendukung produktivitas hidupnya.

8. Kegiatan kelompok pendukung sebaya ini berupa pelatihan public speaking, tujuannya untuk melatih ODHA dan OHIDHA untuk bisa trampil berbicara di depan umum, diskusi atau sharing antar sesama pendamping, dan pelatihan pendidik pengobatan (threatment educator) yang bertujuan untuk melatih mereka untuk menjadi pendamping pengobatan terhadap ODHA yang baru saja memulai threatment. 
9. Hasil penelitian ini menunjukkan bahwa pendamping telah memegang prinsip pendampingan yakni kemauan ODHA untuk membuka status, pemberian informasi dengan baik dan benar, mengakses layanan kesehatan, tidak menularkan kepada orang lain dan melakukan hal yang positif.

10. Tempat pelayanan yang sering digunakan untuk kelompok pendukung dalam melakukan pendampingan terhadap ODHA adalah puskesmas, balai pemasyarakatan, rumah sakit dan BNN. Sesuai KEPMENKES No. 374 Th 2009 tentang Sistem Kesehatan Nasional maka jenjang layanan kesehatan terdiri atas 3 jenjang yaitu sebagai layanan kesehatan primer, sekunder dan tersier (Kemenkes RI , 2012).

11. Anggota kelompok penjangkau memiliki harapan terhadap tenaga pelayanan kesehatan sebagai garda depan terhadap pelayanan kepada ODHA, agar bisa menjadi survivor dalam melanjutkan kehidupannya, antara lain tidak didiskriminasikan dalam pelayanan, tidak mendapatkan stigma di kalangan masyarakat, tidak terlalu masuk dalam ruang pribadi ODHA karena dapat mengganggu trust, hak-hak tsebagai ODHA tetap terlindungi dengan baik.

Berdasarkan hasil penelitian, beberapa saran yang dapat disampaikan oleh peneliti terkait hasil penelitian adalah :

1. Bagi Pendamping

Pendamping sangat berperan dalam memberikan motivasi penderita HIVAIDS dalam menghadapi situasi dan kondisi sebagai ODHA, diharapkan agar tetap berkarya untuk menjadi penyintas dan membantu menjadikan ODHA lain menjadi penyintas yang tangguh dan tetap berkarya.

2. Bagi ODHA

Diharapkan untuk aktif dalam mengikuti program yang dipelrukan seperti pendampingan terapi maupun pendampingan konseling untuk meningkatkan kuailitas hidup dari bernagai aspek kehidupan seperti aspek fisik, sosial, mental dna spiritual.

3. Bagi Pemerintah

Pendamping sangat berperan dalam memberikan motivasi penderita HIVAIDS dalam menghadapi situasi dan kondisi sebagai ODHA sehingga perlu diberikan apresiasi baik dari pemerintan maupun non pemerintah dalam aspek pelayanan kesehatan dan kesejahteran hidupnya

\section{DAFTAR PUSTAKA}

APN+ (January 2004). APN+ position paper 2, GIPA. APN+ \& APCASO (No dates and year). Valued voices: GIPA Toolkit $-A$ manual for the Greater involvement of People Living with HIV/AIDS.

Anonim, (2012)....KDS bagi ODHA dalam (www.odhaberhaksehat.org, 30 
Oktober 2016). KDS bagi ODHA

Awad, dkk, (2015). Perbedaan Tingkat pengetahuan dan Sikap tentang HIV/AIDS pada Waria PSK dan Waria Non PSK di Kota Manado. Dalam Jurnal e-clinic (eCl). Volume 3, Nomor 1. Januari-April 2015.

Creswell.W.J.(2010). Research desaign pendekatan kulaitatif, kuantitatif, dan mixed. Edisi ketiga. Yogyakarta : Sage Publication.Inc

Day, Rosmini (2005). Aspek program pemberian ART untuk IDU di Indonesia. Presentasi dalam pertemuan Tindak Lanjut Lokakarya Aspek Medis Dalam Pengurangan Dampak Buruk, Surabaya, 12-14 September 2005

Dirjen Pemasyarakatan Kementrian Hukum dan HAM ( 2011). Buku Saku Dukungan Sebaya di Lapas dan Rutan . Dirjen Pemasyarakatan Kementrian Hukum dan HAM : Jakarta

Irwanto (2005). Ringkasan: hasil: Pembelajaran aspek teknis program pencegahan HIV/AIDS pada kelompok IDU. Jakarta: Monograph untuk ASA/FH.I

KPA (2003). Strategi Nasional Penanggulangan HIV/AIDS 2003-2007. Jakarta: Kementerian Koordinator Bidang Kesejahteraan Rakyat, Komisi Nasional Penanggulangan AIDS.

KPA ( 2012) ODHA dan AKSES Pelayanan Kesehatan Dasar. Penelitian Partisipatif MAP (2004). AIDS in Asia: Face the Facts. A comprehensive analysis of the AIDS. epidemics in Asia. MAP report.

Kemenkes RI (2012). Layanan Komprehensif HIV-IMS Berkesinambungan.Kemenkes RI 2012.

Kurniawan, Jefri (2013). Dalam blog jerfrikurniawan04.blogspot.co.id/2013/05/05/patogenersis-patofisiologi-dan htnlMesquita, F. (2004). Giving injecting drug users access to highly active antiretroviral therapy as a response to HIV/AIDS epidemic. In IHRD. Breaking down barriers: :Lessons on Providing HIV Treatment to Injection Drug Users. New York: Open Society Institute and International Harm Reduction Development.

Moleong J.L.(2004). Metodologi penelitian kualitatifedisi revisi.Bandung : Remaja rosdakarya.

Shah, Meera K., Zambezi, R., Simasiku, Mary (1999). Listening To Young Voices : Facilitating Participatory Appraisals on Reproductive Health with Adolescence. Focus Tool Series I. Care Intrernational in Zambia. Focus on Young Adults

Stanley.M, Beare.G.P ( 2007). Buku ajar keperawatan gerontik. Edisi 2. Penerbit 
buku kedokteran EGC : Jakarta.

Utama, Andika (2015) . Victory plus pembawa harapan bagi ODHA.dalam citralekha.com/victory. 31 Oktober 2016.

WHO/UNAIDS (June 2005). Summary country profile for HIV/AIDS treatment scale up: Indonesia.

WHO-SEARO (2002) Planing and implementing HIV/AIDS care programe: stepby-step approach. First edition.

Widiayanto,W(2009). Strategi koping penderita HIV/AIDS. Skripsi. Surakarta : Universitas Muhammadiyah Surakarta.Tidak dipublikasikan

Yayasan spiritia (2001). Dokumentasi tentang pelanggaran hak asasi manusia terhadap orang dengan HIV/AIDS di Indonesia. Jakarta : Kelompok Dukungan Sebaya. 